\title{
THE IDEOLOGICAL AND PRACTICAL COMPARISON OF HEZBOLLAH IN LEBANON AND HAMAS ${ }^{\star *}$
}

Ömür KAYA*

Osman ŞEN**

Citation/O: Kaya, Ömür; Şen, Osman, (2014). "The Ideological and Pratical Comparison of Hezbollah in Lebanin and Hamas", Hitit University Journal of Social Sciences Institute, Year 7, Issue 2, pp. 441-455.

Abstract: Hezbollah in Lebanon and Hamas were evaluated within the ideological basis in order to reveal the differences among them. This study presents the ideological and operational differences between the two Islamic visions which depend on understanding of Islam in view of Salafism and Shi'ism. The aspects of organizations are evaluated in three categories such as military, social services, and political actions by considering the size and characteristic features of their actions.

Keywords: Hezbollah, Hamas, Shia, Salafism, Action

\section{Lübnan Hizbullah'ı ve Hamas'ın İdeolojik ve Pratik Karşılaştırılması}

Atıf/O: Kaya, Ömür; Şen, Osman, (2014). Lübnan Hizbullah’i ve Hamas'ın İdeolojik ve Pratik Karşılaştırılması, Hitit Üniversitesi Sosyal Bilimler Enstitüsü Dergisi, Yıl 7, Sayı 2, s. 441-455.

Özet: Lübnan'daki Hizbullah ve Hamas örgütleri aralarndaki farklılıkları ortaya çıkarmak için ideolojik temel içersinde değerlendirme yapılmıştır. Bu çalışma, Selefilik ve Şiilik perpeftifinden iki İslam anlayışı arasındaki ideolojik ve operasyonel farklılıkları sunulmaya çalışılmıştır. Bu örgütlerin operasyonel yönleri, eylemlerinin boyutu ve karakteristik özellikleri dikkate alınarak askeri, sosyal hizmetler ve siyasi eylemler olarak üç kategoride değerlendirilmiştir.

Anahtar Kelimeler: Hizbullah, Hamas, Şii, Selefilik, Eylem.

Makale Geliş Tarihi: 06.05.2014/ Makale Kabul Tarihi: 27.10. 2014

*Ph. D, Police Major, Yozgat Vocational Police School.

** Gazi University, International Relations, Ph. D. Student. 


\section{I.INTRODUCTION}

In the study, after examining the historical background and the improvement stages of Hezbollah in Lebanon and Hamas, which began as the armed resistance groups the Israeli-invasion territories in the Middle East and are now represented by country governments, the ideological and operational differences of these organizations will be deeply evaluated and discussed.

Even though there are many studies which reveal the differences between Hamas and Hezbollah organizations in the literature, there is no research found analysing and describing both ideological and operational differences of them. Archive and interview methods were used in this study as a method for obtaining data. Qualitative techniques have been used to reach the results and to evaluate the data.

Additionally, because this study was planned to be published in a Turkish journal, mainly Turkish sources were studied.

\section{THE HISTORY OF HEZBOLLAH AND HAMAS}

\section{A. The History of Hezbollah}

Hezbollah is an Arabic origin word. The name of Hezbollah is formed from the combination of Hizb and Allah words. The meaning of this word (Hizb) is party, group, and supporter in Turkish. Therefore, Hezbollah can be translated into Turkish as "the supporters of God" or "God's party". The name of Hezbollah is based on the following verses of the Holy Quran by the organization's strategy makers (Boran, 2007: 149).

"Your (real) friends are (no less than) Allah, His prophet Muhammad, and the (fellowship of) believers - those who establish regular prayers and regular charity, and they bow down humbly (in worship)." "As to those who turn (for friendship) to Allah, His prophet Muhammad, and the (fellowship of) believers. - it is the party of Allah that must certainly triumph" Al-Maida verses from 55 to 56 (Kur'ân-1 Kerîm ve Açıklamalı Meâli, 1997: 116).

The foundations of Hezbollah movement can be extended until the actions of Muhammad Sayyid Nevab Safavi. He was born in 1930; went to Najaf (a city in Iraq), which is a holy city for Shiah people, in order to take religious education. Safavi became more radicalized when he was in Najaf, he said that "Islam cannot be built on mass movements; on the contrary, Hz. Muhammad was able to conquer the world through a small number of believers alone, now it is the time to get a gun instead of rosary. Rosary calms, weapons make the enemy to silence against their malice intention. We want to take part from 
scum into a good side or our side. If not, we have to go the path of destroying evil men". Claiming in that view he opened the madrasa in Nacaf (with five guns). Ahmed Kasravi, who was harshly criticized by Ayatollah Khomeini due to his secular rhetoric and actions, was killed by the organization of Safavi. Following this, Safavi changed the name of organization as "Islam Fedayeen" instead of "God's soldiers". In the 1940s, the organization that was led by Safavi increased the number of members. The organization killed many politicians until 1950 (Bulut-2, 1997: 11).

Like other terrorist organizations, Safavi created consepts by using the religious motifs and ideology in order to ensure the legitimacy of its actions and to avoid any difficulty in obtaining the personnel.

After execution of Muhammad Sayyid Nevab Safavi by Iranian government, in the following process, İmam Musa al-Sadr (successor of Nevab Safavi), who was the founder of the the Hezbollah movement in Lebanon, adoted the similar struggling style. After completing his education in the city of Sand (birthplace of Sadr and the Shia scholar educational center), Sadr went to Beirut, which is the capital of Lebanon.

When he was in Iran, Sadr contacted with a secret organization which was called goons of İslam (religios armed group) using the concepts of İslam religion. Also, Sadr has established a relationship with Khomeini (an Iranian politician, religious authority of the nation and a leader of the 1979 Iranian Revolution) when Khomeini's son and his nephew got married. After increasing his political support and power, as soon as Sadr settled in Lebanon, he began to organize the peasants who were tided to the Shiite sect by getting them under the thumb of him (Bulut-2, 1997: 12-13).

Sadr has a charismatic personality with strong rhetoric thanks to his educational background. He gathered a large Shiite group around his periphery in a short time. Sadr, who acts actively in political and social areas, established "Higher Shiite Islamic Council" in 1967. This council was established as official institution (religious institution) to deal with the Lebanon Shiite sect members (Qassam, 2006: 17). Sadr was the president of the council for a long time and pearched in mosques to increase the political awareness (Erdin, 2002: 10).

This action of al-Sadr was one of the most important factors in maintaining complete control over the Shiites of Lebanon.On behalf of an official organization, Shiites were gathered under one roof. Thus, he increased his effect on 
them and managed to organize them more easily. Sadr established "the deprived movement", which acted in political and social areas, in order to reach wider community and to tighten the organizational bonds.

He and members of his movement from different segments of society continued activities on especially migrated people from rural areas and those living in the slums of Beirut. Then, Sadr geared to massive street actions by asserting the social injustices and began to criticize harsly the management of Lebanon. Due to Israel's invasion of Lebanon, Sadr established "Lebanese Resistance Divisions" (EMEL) organization as the military wing of Derived of the Shiite in 1974 to organize the resistance against the invasion in 1974. Sadr said "Israel is only evil in the world and dangerous for muslims,"by this way, he invited Lebanese Shiites to struggle against the Israeli invasion (Qassam, 2006: 17). The Israel invasion made easier to reach its aims and he increased gravitational force of organization by means of making negative propoga against Israel.

With the effect of his education, personal features and existing condition in the country, Sadr conducted Lebanese Shiites to obtain political consciousness and to create the military and political structures in a short time. In the 1970s, Sadr contacted with the Popular Front for the Liberation of Palestine and Fatah organizations in Palestine in order to provide training about asymmetric warfare tactics for his organization members (Bulut-2, 1997: 16).

Sadr disappeared in Libya in 1978 during his visit to this country and could not hear from him again. The disappearance of al-Sadr has further increased spiritual influence of him among supporters.

After Sadr's disappearance, the Islamic Revolution, in 1979, under the leadership of Khomeini in Iran was met with great joy by the Shiites in Lebanon. Khomeini's ideas and success in revolution resonated widely between radicals in Lebanon (Alagha, 2007: 35).

In 1982, discussions that ended with seperation emerged in EMEL movement on what to do after the Israeli invasion. A group from EMEL movement broke and set up the İslamic EMEL movement under the leadership of Sayyed Hossein Mousavi who was the vice president of the EMEL movement at that time. This seperation was mobilized Lebanon's Shiite ulama, "The Nine" Certificate" referred to as a result of discussions on the text, nine representitive from three EMEL movement, including three of them from Bekaa region, and three from the Islamic committees represented this document to the Khomeini who was carrying out the status and authority of Velayat-e Fakihlik at the same time. 
Khomeini approved and signed the document so that the text was gained legitimacy in terms of all Shiites.

In the following process, document put an end to the seperation between the Shiites of Lebanon. All Shiites organized under a single structure named Hezbollah and abolished their former organization. This document had a positive impact on the Shiite cadres. Cadres, by gaining the dynamism again, re-started the intensive propaganda for the public by means of the clergy. Additionally, the clergy tried to indoctrinate the importance of fighting, especially by having weapon training, against Israel to the public on Velayat-e Faqih's advice.

Upon the increase of Hezbollah's effectiveness, Khomeini, who was following a policy that aimed to export his revolution out of the country, took action. While Khomeini met the Lebanese authorities, on the other hand he has started negotiations with Syria to carry out the fight against Israel. After getting positive outcomes as a result of the negotiations, Khomeini secured the deployment of Iran's Revolutionary Guards into Lebanon from Syria territory and at the same time, he charged the Guards to train Lebanase Shias in the camps he made in Lebanon. Hezbollah cadres have developed their ideological and military capabilities as a result of the training they had in these camps (Qassam, 2006: 22-23).

\section{B. The History of Hamas}

Hamas is the abbreviation of Harakat al-Muqawama al-Islamiya and can be translated into Turkish as the Islamic Resistance Movement (İslami Direniş Hareketi) (Bulut-1, 1997:283). Hamas embrace the Palestine conflict and the Muslim Brotherhood organization that has a strong structure in Arab world (Doyran, 2008: 78).

Hassan al-Banna, who was affected by Salafism, founded the Muslim Brotherhood Organization (1hvan-1 Muslimin) in Egypt and this organization became a strong structure in a short time. Hassan al-Banna combined his followers around political objectives and disseminated his thoughts across the Arab geography. Palestinian groups have also been influenced by his Islamic political messages and also political Islam is rooted in Palestine (Burhan, 2008:74).

In fact, Hasan al-Banna sent his brother (Abdurrahman al-Banna) earlier to Palestine in 1935 in order to spread the ideas of the movement. Muslim Brotherhood Organization had a wide mass as of the Great Palestinian Revolt between 1936 and 1939 (Doyran, 2008: 78). His brother's efforts contributed to spread his ideas in Palestine. 
The movement of the Muslim Brotherhood organized in Palestine as of 1935 and fought against Israel in Arab-Israeli War which broke out when Israel declared its independence in 1948, thus it increased its base and support.

The rise of the Muslim Brotherhood in Palestine has been hampered in reaction to the prohibition of Gaza Strip in 1954 and prosecution. On the other hand, the Muslim Brotherhood maintianed its cadres substantially in the West Bank in comparison to Gaza because of the freedoms given by Jordan. This situation has led the Muslim Brotherhood to follow two different strategies in Palestine. While more secretive and militant tactics were applied in the Gaza Strip, they preferred social and political more in the West Bank (Doyran, 2008: 79).

The Muslim Brotherhood's strategy changed completely with Israel's invasion of Palestine in 1967. The Muslim Brotherhood set up a passive action style from the beginning of the invasion to the uprising. In this process, the Muslim Brotherhood gave importance to expand and train their cadres (Doyran, 2008: 80).

Additionally, another important figure of the Muslim Brotherhood in Palestine is Sheikh Ahmed Ismail Hassan Yassin. Sheikh Yassin established an Islamic Complex association in 1973 to spread the ideas of the Muslim Brotherhood. Sheikh Yassin got license for this complex thanks to Sheikh El-Hashim Kazandar's negoiation with Israel. Israel allowed Sheikh Yassin to open the Islamic Coplex because he sided with the peace between Israel and Egypt.

However, the Israeli authorities allowed to built the complex to conduct sports activities. In practice, mosques, schools and clinics were built in the İslamic Complex to increase the effectiveness of the Muslim Brotherhood. While the Israeli authorities recognized their activities and then wanted to restrict this complex, it had already reached a large number of supporters in a short time.

Sheikh Yassin expressed in an interview that they were weak in terms of military training in the 1980s, but in the process, they started piling up arms and come to light with the movement of the Uprising (Chehab, 2009: 34).

The works of the welfare associations that were founded by Sheikh Yassin and the influence of the Muslim Brotherhood's history in Palestine on Palestinian people enabled Hamas to emerge powerfully. The core of Hamas' military wing was established in 1983 by Sheikh Yassin. This structure was called Palestine Mujahedeen when it was established and organized in cell system. Each cell was formed of two or three militants (Chehab, 2009: 47). The name of Izz al 
Qassam, who started an armed struggle against the British invasion of Palestine and subsequently killed by British troops in 1935, was used instead of Palestinian Mujahideen to increase the impact of the organization and give it a historical background (Erdin, 2002: 65-66).

The Muslim Brotherhood in Palestine grew both in quantity and quality and gained a mass characteristic under the leadership of Sheikh Yassin. In 1987, a Palestinian worker died due to car crash. Palestinian people poured into the street because this car belonged to Israel Intelligence Service. This case was just fire for accumulated social problems in Palestine. The revolt activity of the Muslim Brotherhood obtained huge support form Palestinians who were under the poverty and Israel pressure. Sheikh Yassin declared the establishment of Hamas by using the uncontrollable revolt on 14 December 1987. During the first uprising, Hamas published the first manifest and announced its roadmap (Bulut-1, 1997: 283).

\section{IDEOLOGICAL COMPARISON OF BOTH ORGANIZATIONS}

When Hamas'Declaration of Establishment, dated 18 August 1988, was examined (Haması'in Kurtuluss Bildirgesi, 2009), it is seen that the organization is a Palestinian Islamic movement and it is a wing of the Muslim Brotherhood, that a complete understanding of the Muslim Brotherhood was adopted into the ideology of Hamas. Hamas chose the Islamic Jihad path against the Zionism as a perceived religious duty. The supporters believe that the root of the movement depends on Shaheed Izzeddin al-Qassam and the fighters of the Muslim Brotherhood in 1939. The expectation of supporters is to want the Islamic life style and to terminate the Zionism.

The ideology of Hamas depends on the Muslim Brotherhood which has an understanding of Islamic-Salafism. The goal of Hamas is to establish an Islamic regime in Palestine after destroying Israel as a result of the armed struggle (Jihad with Israel) (Mohammed, 2001: 140).

The open letter was published on 15 February 1985 by Hezbollah. The analysis of this letter indicates that Hezbollah's ideology was shaped under the leadership of Ayatollah Khomeini and his orders which fought against the U.S., Israel, France and the Phalangists by using Jihad (Qassam, 2006: 307329): One of the main goals of Hamas is to rescue the Lebanese territory from the Israel invasion and is to establish an Iranian-style Islamic State in Lebanon. Also Hamas see America as the great devil. Additionally, this document revealed the real objective of Hamas, which is not only Lebanon but also the whole region. 
When the declarations of Hezbollah are examined, it is seen that the ideology of Hezbollah is clearly based on Shi'ism and Ayatollah Khomeini was accepted as the leader, that Hezbollah preferred jihad as a struggle method (violence path) with the enemies and its ultimate goal is to build an Islamic regime.

When both Hezbollah and Hamas' documents are evaluated, it is concluded that the key point of the differentiation of both organizations is the understandings of Salafism and Shi'ism. Hamas sees Palestine as its activity area in general terms, on the other hands, Hezbollah sees the whole region as its activity area. Hezbollah described its enemies largely and clearly while Hamas used a vague expression such as Israel and the ones that conducive it.

Although these two organizations may seem very similar to each other, the difference in their understandings can be understood clearly by examining the basic differences between Shiism and Salafism.

In Salafism, looking the nass and apparent side is accepted as the basic principle to understand the religion. They accept the religious texts (the Qur'an and the hadith) with their letters only and without mental interpretation (Jurisprudence and te'vil). They also do not accept the interpretation of religious texts based on social sciences, philosophy, history and sociology.

As a fundamental principle of faith in Salafism, faith cannot be reachable with mentally. According to them, the truth of faith is absolute devotion to the orders of Quran and Hadith (nass), performing the orders and avoiding the prohibited things by Quran and Hadith. In more technical terms, faith includes deeds in Salafism. This idea was designated first by Kharijites in Islamic thought and was maintained by salafism. Therefore, if the deeds are not performed by one Muslim, he or she is accepted as takfir (or takfeer) and the takfir's (kafir) life and property can be taken according to this view. According to Ibn Taymiyyah, who is one of the important figures in Salafism, the jihad is an essential part of the faith as a deed.

So the action or actions to oppose blasphemy under all conditions is a task that every believer must fulfill. In the understanding of Salafism, if a person does not obey the religious orders and refrain from bans, he becomes takfir even if he says that I am Muslim. This person has no difference from non Muslim or kafir (unbeliever), so his soul and property becomes halal. 


\section{SOME BASIC DIFFERENCES BETWEEN SHIISM AND SALAFISM}

1-The determination of the imam in Shiism is with nass and it is acknowledged that the imam comes from the descendants of Ali. On the otherhand, salafism does not accept the selection of the imam with nass.

2-The Shia imam is believed to be innocent and is protected by revelation in Shiism, but Salafism does not accept the innocence of any mankind and it accepts the attribution of innocence to mankind as a major shirk.

3- The sequence of the first four caliphs does not indicate superiority and also indicates the seizure of the caliphate in Shiism. Salafism accepts the traditional hierarchy, in other words, it confirms the superiority of one another in the order of caliphate.

4- Shiism only accepts the authority of companion who is in the line of Ehlibeyt (the family of the Prophet Muhammed). Salafism respects the authority of the companions of the Prophet Muhammad. In this sense, the meaning of respect is to accept the validity of the authentic hadiths from the companions of the Prophet.

5- Shia accepts tev'vil and jurisprudential as a method of understanding the religion. In this sense, Fakih (canonist) institutions were established. Salafism does not accept te'vil but accept ijtihad and they do not generalize the rule of ijtihad (that is accepting the difference of opinion) upon differences in Aqeedah.

Salafism has engaged into regional conflicts with Shi'ism due to its historical roots. While Salafism and Shi'ism are different from each other because of their basic understandings, the modern Salafism and the Shia movement come closer against the West, which is their common enemy (Demir, 2010).

\section{THE DIFFERENCES OF HAMAS AND HEZBOLLAH IN MILITARY AC- TIONS}

When the two organizations are compared with regards to military actions, it is seen that both have conducted asymmetric warfare against their enemies. Both organizations see suicide bombers or martyr (shaheed in their own words) as necessary. Also, both of them performed hostage-taking acts at different time for prisoner exchange.

The security wing of Hamas got the orders from Sheikh Yassin. Under the direction of his orders, security wing used to publish warnings firstly before taking action. When the warnings were not taken into consideration by the 
followers, they were punished for the death penalty after being interrogated with broader questions and with a signed confession and record. They shared the confessions and the cases with public and pasted their posters to the streategic places as Hamas' message in order to obtain deterrent effect on the followers.

Every organization has activities against the collaborators, but Hezbollah did not use the confessions of the collaborators to inform the public. There is no information in open sources about this case (Chehab, 2009: 49).

When we look at the actions of Hamas militants, the following events are listed: killing sheep merchant David Cohen on May 17, 1992, stabbing two bottling citrus workers in Kibbutz Nahal Oz on June 25, 2002, suicide attack to the bus station in Afula and killing eight Israelis and injuring 44 as a result on April 6, 1994 (Chehab, 2009: 74).

When we examine the actions of Hezbollah militants, they can be examplified as follows: the truck bomb attack to the U.S. Marines on October 23, 1983 when 241 American and 58 French soldiers were killed, 100 people were killed in July 1994, a result of the bombing of Argentine-Israeli Cooperation and Solidarity Association building (Erdin, 2002:36-37).

It is possible to give more examples about the actions of these organizations. When we look at their actions, it can be said that Hamas selects its targets randomly, which is called blind-terror, and does not avoid hitting civilian. Hamas has also no big successful action outside of Palestine. On the other hand, Hezbollah is more selective and its primary targets are military targets. Unlike Hamas, it appears that Hezbollah performed big actions abroad and they are more successful than Hamas.

Qassam rockets are Hezbollah's own manufacture and were used against Israel (Chehab, 2009: 85). Qassam rockets have a 10 kilometers range and they can carry up to twenty kilogram explosive. Nowadays, a large part of the stock of Hezbollah is composed of Katyussa, 122-millimeter, cannonball-shaped rockets (Boran, 2007: 293). In addition, Hezbollah kept shelling the area to prevent Israel from taking the death bodies of Israeli soldiers who were killed as a result of real promise operation on 12 July 2006 (Chehab, 2009: 87).

In the light of the above mentioned issues, it is seen that Hezbollah uses more professional and heavy weapons than Hamas when their arsenals are compared. 


\section{IN TERMS OF SOCIAL SERVICES}

HAMAS and Hezbollah acted similarly about the social services such as education and health care that the governments could not bring or failed to satisfy for a long time and both of them gained the sympathy of the people. These infrastructure works provided a basis for finding soldiers for the armed wings and for the political successes that will be explained at the following heading. There is no appreciable difference in terms of social services between two organizations.

\section{DIFFERENCES IN TERMS OF POLITICAL ACTIVITY}

There is a big difference between the word "intifada" which can be translated into Turkish as "shaking off, getting up, rebelling" and the protest activities that were carried out by Hezbollah in Lebanon. "Intifada" is total rebellion of a nation against oppression (Kodaman, 2006:186).

Sheikh Yasin evaluated the signing of Oslo agreements as a positive development and he sent a letter from jail in 1993 to call for restraint to members of Hamas. Also, he ordered the members of Hamas to join the election in his letter. Ismail Haniye who is the leader of Hamas, comformed to Sheikh Yassin's calling and joined the election in 1996. He has been the president of Palestine Self-Government in the elections of 2006 (Chehab, 2009: 130).

Also, Hezbollah got Khamenei's opinion, whom they see as religion qua Velayat-e Faqih, about the legitimacy of joining the elections. After Khamenei's positive fatwa about this subject, Hasan Nasrallah, the General Secretary of Hamas, joined elections in 1992 (Qassem, 2006: 204).

When Hezbollah's election program in 1992 were examined, it is seen that Hezbollah prepared a very comprehensive program under the following headings: bringing opposition, religion and sect based politics to an end, election law, political freedoms and freedom of the press, forced migration, administration, social and educational isues (Alagha, 2007: 271-278).

In the same way, Hezbollah's 1996 parliamentary election program, 2000 parliamentary election program and 2005 election programs were under seven main headings (Alagha, 2007: 271-278). The number of members of Hezbollah in parliament was 12 of 128 people in 1992 (Alagha, 2007: 301), 11 members in 1996 election (Alagha, 2007: 303) and 12 members in 2000 elections (Qassam, 2006: 206). Hezbollah had 14 representing members in parliament and had two ministers in the cabinet in 2005 (Alagha, 2007: 310). 
As a result of pressure from the U.S. and France, Hezbollah could not get the important ministries such as the Ministries of Defense and Foreign Affairs. They achieved to take the Ministry of Energy and the Ministry of Labour (Işitan, 2008: 85).

Hezbollah stated to fight against Israel as the first article of party program in all elections they had joined. Another important point is that Hezbollah gave place to cooperation with other groups living in Lebanon in the party programs in order to increase the legitimacy of the Hezbollah. Hezbollah succeeded in inserting their representatives to parliament in every election. They choosed their candidates not only fom Shiites but also fom Sunni and Christians in Lebanon and succeeded in bringing them to parliament (Işitan, 2008: 85).

While there are some perspectives like Hezbollah will be an Islamic party only in discourse in the following process, but in practice it can change the direction towards a semi-secular state as a result of the political conditions (Diane, 2003: 114), their own sources state that politics and resistance support each other.

In 2005, Hamas boycotted the presidential elections in Palestine and the election ended up with the victory of Mahmoud Abbas. Then, Hamas participated in the parliamentary elections in 2006 and won 76 seats in parliament against Al-Fatah (43 seats) (Burhan, 2008: 118). However, a stand-alone Hamas could not establish the government. The friction occurred between them. They established the government together with the mediating efforts of Saudi Arabia. Later Hamas leader Ismail Haniyeh has been Prime Minister of the Government of the Union (Burhan, 2008: 122).

According to Hamas member Dr. Osama Elşagar, Hamas won the election with "Resistance and Reform" slogans. Osama Elşagar (Taşkın, 2007: 216), one of the most important figures, defined Hamas' new target as fighting against corruption and unemployment (Aksiyon Haber, 2013).

It is clearly seen that the party program of Hezbollah is more comprehensive than Hamas, but Hamas is more successful than Hezbollah in the political arena and has been in the Government since 2007.

While Hamas and Hezbollah have obtained considerable achievements in the political area, they are not successful enough in practising their programs and have trouble due to disarmament. One of the major reasons for this is that the super power United States considers these organizations as terrorist groups and their financial resources are frozen. 
Both organizations seem to try to find a solution to this problem by taking Israeli soldiers as hostages. Israel launched a large-scale operation on June 28, 2006 when a group of militants of Izz Al Qassam Brigades, which is the military wing of Hamas, dug a tunnel to Israel took 19 years old Israeli soldier Gilat Shalit as a hostage on June 25. As well as the operation, Israel took politicians, including nine ministers and parliamentarians of Hamas, into custody.

After that, Hezbollah's military wing (the Islamic Resistance in Lebanon) announced that two Israeli soldiers were kidnapped on July 12 and Israel started to attack on Lebanon on July 13 (Boran, 2007: 211-213). ${ }^{46}$

As a result of Israel attacks, both organizations took high proportion of foreign aid, the number of their supporters increased and a public opinion was created for the necessity of being armed.

\section{CONCLUSION}

The main separation point of Hezbollah and Hamas' ideologies is the understanding of Shisim and Salafism. Hamas sees Palestine as a field of activity in general terms. However, Hezbollah sees the scope of its activities as regional. Hezbollah described its enemies clearly, but Hamas used a vague expression for his enemies like Israel and those who help it.

Although the two organizations may seem very similar, their basic understanding differences can be seen clearly when differences between Shiism and Salafism are examined. They have very different understandings about imamate the innocence of the Imam, revelation issue, sequence of the first four caliphs, the authority of companions and fakih institutions. It is clear that these key issues can lead to great differences in the organization of the daily life of the groups. Historical roots of Salafism clashed with Shi'ism about regional conflicts. However, modern Salafism and the Shia movement converged with each other today against the West as a common enemy.

Interms of military actions of both organizations, it is clearly seen that both of them conduct an asymmetric warfare against their targeted enemies. Either Hamas or Hezbollah consider suicide bombers, or martyr actions in their words, as necessary. They performed hostage-taking actions at different times in order to exchange the prisoners.

Both of them have activities against the collaborators. However, Hamas prefers to inform the public about the confession of the collaborators in order to ensure deterrence among the supporter, but Hezbollah does not use this way and no open source reveals information about this issue. 
The actions of Hamas show that it selects targets randomly, which can be called blind terror, it is not precise about not hitting the civilian targets and it has no a great, successful action outside Palestine. On the other hand, Hezbollah appears to be more selective than Hamas and it principally selects military targets. Unlike Hamas, Hezbollah performed great actions abroad, too. It seems that Hezbollah has greater and more successful actions than Hamas.

Hezbollah uses more professional and heavy armors than Hamas.

In terms of social services, there is no significant difference between Hamas and Hezbollah.

There is big differences between the Intifada protests of Hamas and the protest actions that were carried out by Hezbollah in Lebanon. Intifade is total rebellion of a nation against the oppression.

The party programs of Hezbollah are more comprehensive than Hamas, but Hamas has been more successful in the political arena than Hezbollah and it has been in the government since 2007 .

Overall, it can be explained that there are operational, ideological, political and military differences between Hamas and Hezbollah.

The development and recruitment of these organizations depend on the condonations of active forces in international community to the violation of human rights and international law by Israel and West. It is clear that radicalization will damage the people all over the world. In this respect, in order to prevent radicalization, it is necessary to conduct the international law equally for all sides and the necessary pressure should be done for Israel by international community to force it act properly with international law.

\section{REFERENCES}

ALAGHA, Joseph Elie. (2007), Silahlı Mücadeleden İktidar Partisine Hizbullah, Doğan Kitap, İstanbul.

BORAN, Yıldırım. (2007), Lübnan' daki İran Hizbullah, Siyah Beyaz Basım Yayın Dağıtım, İstanbul.

BULUT (1), Faik. (1997), İslamcı Örgütler-1, Doruk Yayıncılık, Ankara Genişletilmiş 3. Bask1.

BULUT (2), Faik. (1997), İslamcı Örgütler-2, Doruk Yayıncılık, Ankara Genişletilmiş 3. Bask1. 
BURHAN, Ali. (2008) Filistin-İsrail çatışması ve HAMAS, Yüksek Lisans Tezi, Süleyman Demirel Üniversitesi, Isparta.

DOYRAN, Ersin. (2008), Bir Direniş Hareketi Olarak: Hamas, Elips Kitap.

CHEHAB, Zaki. (2009), Hamas, İkarus Yayınları, İstanbul.

DEMİR, Hilmi. (2010), An Interview with Assitant Professor Hilmi Demir at Hitit University, in 01.01.2010, Time: Between 14.00 and 14.40.

ERDİN, Murat. (2002), Hizbullah ve Hamas, Kastaş Yayınevi, İstanbul.

KODAMAN, Timuçin ve SARAÇ Esme. (2006), "Hamas", Akademik Orta Doğu Dergisi, Cilt 1, Sayı 1, ss. 177-197.

MOHAMMED, M. Hafez. (2001), “The Ideology of Hamas by Andrea Nusse”, International Journal of Middle East Studies, Vol. 33, No. 1, pp. 139-141, (erişim adresi: http:// www.jstor.org/stable/259493), (Erişim Tarihi: 20.03.2014).

QASSAM, Naem. (2006), Hizbullah, Kesit Yayınları, İstanbul.

TAŞKIN, Hasan. (2007), İsrail, Hamas, Hizbullah Kıskacında Türkiye, Neden Kitap Yayınc1lık, İstanbul, 2007.

DİANE, Riskedahl. (2003), "Hizbullah: Politics and Religion by Amal Saad-Ghorayeb", Journal of Palestine Studies (University of California Press on behalf of the Institute for Palestine Studies), Vol.32, No.3, pp.113-114, (erişim adresi: http:// www.jstor.org/stable/3247349), (erişim tarihi: 22.03.2014).

TAMIMI, Azzam (2008), "Hamas: a history from within", Northampton, MA, Olive Branch Press, (erişim adresi: http://rac.sagepub.com at Middle East Technical University), (erişim tarihi: November 20, 2009).

"Hamas'in Kuruluş Bildirgesi” (Erişim adresi: http://www.velfecr.net), (erişim tarihi: 16.12.2009).

IŞITAN, Rıza. (2008), Terörizm, İslamcılık ve Hizbullah, Yüksek Lisans Tezi, Karadeniz Teknik Üniversitesi, Trabzon. 
